\title{
Estimation of Serum Uric Acid Levels in Bangladeshi Gestational Diabetic Mothers Attending a Tertiary Care Hospital
}

\author{
Mishu FA ${ }^{\mathrm{a}}$, Muttalib MA ${ }^{\mathrm{b}}$, Yesmin $\mathrm{MS}^{\mathrm{c}}$, Sultana GS ${ }^{\mathrm{d}}$, Ferdous $\mathrm{N}^{\mathrm{e}}$, Shamsunnahar ${ }^{\mathrm{f}}$
}

\begin{abstract}
Background: The hyperuricaemia in gestational diabetes mellitus (GDM) has been explained to be a component of the metabolic syndrome which reflects insulin resistance. Gestational huperuricaemia was found to be significantly associated with a high rate of maternal and foetal complications along with proteinuria and hypertension. Aims of this study were to evaluate the serum uric acid levels in Bangladeshi women with GDM in their second and third trimesters of pregnancy.
\end{abstract}

Methods: This descriptive cross-sectional study was conducted at Mymensingh Medical College Hospital from July 2013 to June 2014. Pregnant women, in their second and third trimester, attending the outpatient department of Obstetrics and Gynecology and the Department of Endocrinology were enrolled by purposive sampling technique. GDM was diagnosed on the basis of oral glucose tolerance test (OGTT) as defined in WHO criteria 2013.

Results: Out of 172 participants, 86 had GDM (case) and 86 were normoglycemic (control). The mean age of GDM and control groups was $28.6 \pm 3.2$ years and $27.3 \pm 3.1$ years respectively. The BMI was $26.4 \pm 1.5 \mathrm{~kg} / \mathrm{m}^{2}$ and $26.3 \pm 1.3 \mathrm{~kg} / \mathrm{m}^{2}$. In this study we found serum uric acid levels in GDM and without GDM were $4.47 \pm 0.42$ $\mathrm{mg} / \mathrm{dl}$ and $4.48 \pm 0.41 \mathrm{mg} / \mathrm{dl}$ respectively ( $p>0.05$ ). Serum uric acid level in GDM group was significantly $(p<0.001)$ higher in third trimesters $(4.48 \pm 0.41 \mathrm{mg} / \mathrm{dl})$ compared to those without GDM $(3.52 \pm 0.74 \mathrm{mg} / \mathrm{dl})$.

Conclusion: There was distinct alteration of serum uric acid level in GDM compared to normal pregnancy. Estimation of serum uric acid levels might be incorporated in every GDM cases for prevention of complications.

Key words: Oral glucose tolerance test, second trimester, third trimester. hyperuricaemia.

(BIRDEM Med J 2019; 9(1): 55-58)

\section{Author Information}

a. Dr. Farzana Akonjee Mishu, Assistant Professor,Department of Physiology and Molecular Biology, Bangladesh Institute of Research \& Rehabilitation in Diabetes, Endocrine \& Metabolic Disorders (BIRDEM) Dhaka, Bangladesh.

b. Dr. MA Muttalib, Professor of Biochemistry and Laboratory Coordinator General Laboratory (Biochemistry and Laboratory Medicine), BIRDEM, Dhaka, Bangladesh.

c. Dr. Mst. Shaila Yesmin, Assistant Professor of Laboratory Medicine, BIRDEM, Dhaka, Bangladesh.

d. Dr .Gazi Sharmin Sultana, Associate Professor of Laboratory Medicine, BIRDEM, Dhaka, Bangladesh.

e. Dr. Nadia Ferdous, Assistant Professor of Biochemistry, Tairunnesa memorial Medical College, Dhaka, Bangladesh.

f. Dr. Shamsunnahar, Assistant Professor of Biochemistry, President Abdul Hamid Medical College Kishorgonj, Bangladesh.

Address of Correspondences: Dr. Farzana Akonjee Mishu, Assistant Professor, Department of Physiology and Molecular Biology, BIRDEM, Dhaka, Bangladesh. Email: farzanamishu@ yahoo.co.uk Received: January 2, 2018 Accepted: October 31, 2018

\section{Introduction}

Gestational diabetes mellitus (GDM) is defined as carbohydrate intolerance resulting in hyperglycemia, with first onset or detection during pregnancy. 1,2 Usually initiation of GDM is in middle and late gestational period and continues to term. ${ }^{3}$ Glucose intolerance usually returns to normal range within six weeks after delivery. Approximately 1-14\% of all pregnancies are complicated by GDM. ${ }^{4}$ The prevalence of GDM among Bangladeshi pregnant mothers has been reported as $9.7 \% .^{5}$ GDM is characterized by insulin resistance, glucose intolerance, hyperlipidaemia, impaired beta cell function and endothelial dysfunction like type 2 diabetes and metabolic syndrom ${ }^{6}$

Uric acid is the end product of the purine metabolism. Uric acid can act as a prooxidant and it may thus be a marker of oxidative stress, but it may also have a 
therapeutic role as an antioxidant. ${ }^{7}$ Urate, the soluble form of uric acid, can scavenge the superoxide and the hydroxyl radicals and it can chelate the trasition metals. ${ }^{8}$ Hyperuricaemia has been also added to the set of metabolic abnormalities which are associated with insulin resistance and/or hyperinsulinaemia in the metabolic syndrome. ${ }^{9}$ The raise uric acid levels in GDM is a component of the metabolic syndrome that reflects insulin resistance. ${ }^{10}$ The hyperuricaemia in GDM has been explained to be a component of the metabolic syndrome which reflects insulin resistance. Further hyperuricaemia has been correlated with obesity, dyslipidaemia and diabetes mellitus. ${ }^{11}$

Gestational huperuricaemia was found to be significantly associated with a high rate of maternal and foetal complications along with proteinuria and hypertension. ${ }^{12}$ Hyperinsulinaemia may activate the sympathetic nervous system and both of them may be independently associated with a reduced urinary excretion of uric acid.

This study was designed to evaluate serum uric acid level among patients with GDM.

\section{Methods}

The study was conducted at Mymensingh Medical College Hospital from July 2013 to June 2014 to evaluate the serum level of uric acid in pregnant women with GDM. The study protocol was approved by the institutional review committee and written informed consent was obtained from all the participants prior to their enrolment into this study.

Study population and collection of samples: Pregnant women, in their second and third trimester, attending the outpatient department of Obstetrics and Gynecology and the Department of Endocrinology of Mymensingh Medical College Hospital were enrolled by purposive sampling technique. Pregnant women with the previous history of diabetes, hypertension and other endocrine disorders were excluded from the study. Data were collected in a predesigned data collection sheet. The variables included were - age, height, weight, duration of gestation, family history of diabetes, previous history of pregnancy and gestational diabetes mellitus. About $5 \mathrm{ml}$ of blood was collected aseptically with venipuncture from all participants for OGTT and estimation of serum uric acid levels.

Estimation of serum glucose and uric acid: Blood glucose was estimated by enzymatic GOD-PAP colorimetric method. ${ }^{13}$ GDM was diagnosed on the basis of OGTT as defined in WHO criteria 2013. 1, 14
The cut off value for fasting plasma glucose level was e"6.1 mmol/L or e"7.8 mmol/L 2 hours after glucose load. Serum uric acid was determined by commercial colorimetric assay kits obtained from Japan Institute for the Control of Aging (JaICA), Nikken Seal Co., Ltd, Japan. Serum uric acid by enzymatic method with Uricase as per manufacturer's instruction. ${ }^{15}$

The results were analyzed by employing Student's t test and values were expressed as mean $\pm \mathrm{SD}$. The level of significance was determined $\mathrm{p}<0.5$

\section{Results}

A total of 172 pregnant women in their second and third trimester were enrolled in the study, of which 86 had GDM and 86 were normoglycemic. Pregnant women without GDM (normoglycemic) were considered as control group. The mean age of GDM and control groups were $28.6 \pm 3.2$ years and $27.3 \pm 3.1$ years respectively, while the mean BMI was $26.4 \pm 1.5 \mathrm{~kg} / \mathrm{m}$ 2 and $26.3 \pm 1.3 \mathrm{~kg} / \mathrm{m}^{2}$ respectively (Table I). Serum uric acid levels in GDM cases were significantly $(\mathrm{p}<0.001)$ higher in third trimester $(4.33 \pm 0.62 \mathrm{mg} / \mathrm{dl})$ compared to those without GDM $(3.52 \pm 0.74 \mathrm{mg} / \mathrm{dl})$. But there was no significant rise of serum uric acid levels compared to second trimester in both GDM and non GDM cases (Table II).

Table I Age and BMI of study population

\begin{tabular}{lcc}
\hline Group & Age $(\mathrm{yrs})$ & $\mathrm{BMI}\left(\mathrm{kg} / \mathrm{m}^{2}\right)$ \\
\hline GDM & $28.6 \pm 3.2$ & $26.4 \pm 1.5$ \\
Control & 27.33 .1 & $26.3 \pm 1.3$ \\
p value & 0.778 & $0.778 \mathrm{G}$ \\
\hline
\end{tabular}

DM-Gestational diabetes mellitus; Control-Pregnant women without GDM ( Euglycemic)

Table II Serum concentration of uric acid in GDM and euglycemic women

\begin{tabular}{|c|c|c|c|}
\hline \multirow[t]{2}{*}{ Group } & \multicolumn{3}{|c|}{$\begin{array}{c}\text { Mean } \pm \text { SD Concentration of serum } \\
\text { Uric acid in }(\mathrm{mg} / \mathrm{dl})\end{array}$} \\
\hline & $2^{\text {nd }}$ trimester & $3^{\text {rd }}$ trimester & Total \\
\hline GDM & $4.47 \pm 0.42$ & $4.47 \pm 0.41$ & $4.47 \pm 0.41$ \\
\hline Control & $4.43 \pm 0.62$ & $3.52 \pm 0.74$ & $3.93 \pm 0.79$ \\
\hline p-value & 0.256 & 0.001 & 0.001 \\
\hline
\end{tabular}




\section{Discussion}

Uric acid is filtered by the renal glomeruli, absorbed by the first part of the proximal convoluted tubule, with a further secretion and reabsorption phase. Ten percent of the filtered uric acid is excreted in the urine. During pregnancy, uric acid clearance increases from 6 to 12 $\mathrm{mL} / \mathrm{min}$ to 12 to $20 \mathrm{~mL} / \mathrm{min}$, with a $25 \%$ decrease in blood concentration. ${ }^{9}$ Elevated serum uric acid level due to decreased renal urate excretion is frequently found in women with preclampsia. ${ }^{16}$ Uric acid (as also creatinine and to some extent urea), possesses water soluble or hydrophilic antioxidant characteristics, may delay or inhibit cellular damage mainly through the free radical scavenging property; it also presents strong antioxidant activity towards ROS in aqueous phase. ${ }^{17}$ Uric acid contributes to about $60 \%$ of free radical scavenging activity in human. ${ }^{18}$ The observed uric acid elevation may be a protective response, capable of opposing harmful effects of free radical activity and oxidative stress. Elevated serum uric acid concentrations predict the development of hypertension. ${ }^{19}$ Soluble uric acid impairs nitric oxide generation in endothelial cells thus inhibit vascular relaxation. Hence, hyperuricemia can induce endothelial dysfunction (impaired endothelial integrity). ${ }^{19,20}$ It has been proposed that these pregnancy mediated changes in serum uric acid are often the result of altered renal handling. ${ }^{19,20,21}$ In this study uric acid levels were higher in the GDM patients, this elevation was statistically highly significant. In univariate analysis, gestational hyperuricaemia was found to be significantly associated with a high rate of maternal and fetal complicatons, along with proteinuria and hypertension .12 Hyperinsulinaemia may activate the sympathetic nervous system and both of them may be independently associated with a reduced urinary excretion of uric acid. Thus, the raised serum uric acid levels may reflect both these mechanisms and some researchers. found that serum uric acid was significantly correlated with insulin resistance. ${ }^{15,22}$ Seghieri et al. (2003) reported that GDM remained significantly associated with higher serum uric acid levels.${ }^{16}$ Our findings is supported by the studies of Danisman and Mollamahmtuglu (2006)..$^{20}$

\section{Conclusion}

The present study has revealed that there is pronounced alteration of serum uric acid levels in GDM cases compared to normal pregnancy. Therefore, further study should be done to find out the underlying mechanism of alteration of serum uric acid levels in GDM.

Conflict of interest: Nothing to declare.

\section{References}

1. Diagnostic criteria and classification of hyperglycaemia first detected in pregnancy: a World Health Organization Guideline. Diabetes Res Clin Pract 2014; 103: 341-63.

2. Buckley BS, Harreiter J, Damm P, Corcoy R, Chico A, Simmons D, Vellinga A, et al. Gestational diabetes mellitus in Europe: prevalence, current screening practice and barriers to screening. A review. Diabet Med 2012; 29(7): 844-54.

3. Gokcel A, Bagis T, Killicadag EB, Tarim E, Guvener N. Comparison of the criteria for gestational diabetes mellitus by NDDG and Carpenter and Coustan, and the outcomes of pregnancy. J Endocrinol Invest 2002; 25: 357-61.

4. Kim C, Newton KM, Knopp RH. Gestational diabetes and the incidence of type 2 diabetes. Diabetes Care 2002; 25: 1862-68.

5. Jesmin S, Akhter S, Akashi H, Al-Mamun A, Rahman MA, Islam MM, et al. Screening for gestational diabetes mellitus and its prevalence in Bangladesh. Diabetes Res Clin Pract 2014; 103(1): 57-62.

6. Innes KE, Byers TE, Marshall JA, Baron A , Orleans M, Hamman RF. Association of a women's own birth weight with subsequent risk for gestational diabetes. JAMA 2002; 287:2534-41.

7. Patterson RA, Horsley E TM,Leake DS. The prooxidant and the antioxidant properties of the human serum ultrafiltrates towards LDL: the important role of uric acid. J Lipid Res 2003; 44 (3):512-21.

8. Ames BN, Cathcart R, Schwiers E, Hochstein P. Uric acid provides an antioxidant defence mechanism in humans against oxidants and radicals which cause aging and cancer: a a hypothesis. Proc Natl Acad Sci USA 1981;78: 6858-62.

9. Nakagawa T, HuH, Zharikov S, Tuttle KR, Short RA, Glushakova O, et al. A causal role of uric acid in the fructoseinduced metabolic syndrome. Am J Physiol Renal Physiol 2005;290:625-31.

10. Güngör ES, Danisman N and Mollamahmutoglu L. Relationship between serum uric acid, creatinine, albumin and gestational diabetes mellitus. Clin Chem Lab Med .2006;44:974-77.

11. Danisman N and Mollamahmtuglu L.Relationship between serum uric acid,creatinine, albumin and gestational diabetes mellitus. Clin Chem Lab Med 2006;44:974-77.

12. Brown MA. Buddle ML. Hypertension in pregnancy: maternal and fetal outcomes according to the laboratory and clinical features. Med J Aust 1996;165:360-65. 
13. Trinder P. Determination of glucose in blood using glucose oxidase with an alternative oxygen acceptor. Ann.Clin. Biochem 1969; 6: 24-27

14. WHO Consultation: definition, diagnosis and classification of diabetes mellitus and its complications: report of a WHO Consultation.Part 1: diagnosis and classification of diabetes mellitus. Geneva, WHO/NCD/NCS/99. 2:World Health Organization; 1999.

15. Verdecchia, P., Schillaci, G., Reboldi, G., Santeusanio, F., Porcellati, C. and Brunetti, P.The correlation between serum uric acid and the risk of cardiovascular disease in essential hypertension - The PIUMA study. Hypertension 2000;36(6): 1072-78

16. Seghieri, G., Breschi, M.C., Anichini, R., De, Bellis, A., Alviggi, L., Miada, I. et al. Serum homocysteine levels are increased in women with gestational diabetes mellitus. Metabolism 2003;52:720-23.

17. Ames BN, Cathcart R, Schwiers E, Hochstein P. Uric acid provides an antioxidant defense in humans against oxidantand radical-caused aging and cancer: a hypothesis. Proc Natl Acad Sci USA 1981;78:6858-62.
18. Waring WS. Antioxidants in prevention and treatment of cardiovascular disease. Proc R Coll Physicians Edinb 2001; 31:288- 92 .

19. Manjareeka M, Nanda S. Elevated level of serum uric acid, creatinine or urea in preeclamptic women. Int J Med Sci Public Health 2013;2:43-47.

20. Sendhav S, Khubchandani A, Gandhi P, Sanghani H, Sidhu G, Vadhel A. A Comparative Study Of Serum Uric Acid, Calcium and Magnesium In Preeclampsia and Normal Pregnancy. JARBS 2013;5:55-58.

21. Lam C, Lim KH, Kang DH, Karumanchi SA. Uric acid and preeclampsia. Semin Nephrol 2005;25:56-60.

22. Woo Yoo, T., Sung, C.K., Shin, H.S., Kim, B.J., Kim ,B.S, Kang, J.H, et al. Relationship between serum uric acid concentration and insulin resistance and metabolic syndrome. Circ J 2005;69:928-33.

23. Williams KP, Galerneau F. The role of serum uric acid as a prognostic indicator of the severity of maternal and fetal complications in hypertensive pregnancies. J Obstet Gynaecol Can 2002;24: 628-32. 